\title{
VERIFICATION OF AUTHENTICITY OF GINKGO BILOBA L. LEAF EXTRACT AND ITS PRODUCTS PRESENT ON THE CROATIAN MARKET BY ANALYSIS OF QUANTITY AND RATIO OF GINKGO FLAVONE GLYCOSIDES (QUERCETIN, KAEMPFEROL AND ISORHAMNETIN) TO TERPENE TRILACTONES TO THE EFFECT OF UNMASKING COUNTERFEIT DRUGS ENDANGERING PATIENT HEALTH
}

\author{
Maja Budeč ${ }^{1}$, Jasna Bošnir ${ }^{1,2}$, Aleksandar Racz ${ }^{2}$, Dario Lasic ${ }^{1}$, Danijel Brkić ${ }^{1}$, \\ Ana Mosović Ćuiće ${ }^{2}$ Željka Kuharić ${ }^{1}$, Gordana Jurak ${ }^{1}$ and Lidija Barušić ${ }^{1}$ \\ ${ }^{1}$ Andrija Štampar Teaching Institute of Public Health, Zagreb, Croatia; \\ ${ }^{2}$ University of Applied Health Studies, Zagreb, Croatia
}

\begin{abstract}
SUMMARY - Ginkgo biloba L. is the eldest plant growing on the Earth; preparations made of its leaves and seeds represent an integral part of the Chinese medicine for over a millennium. The plant species was first discovered by Linnaeus in 1771, its name thereby originating from the Latin words bis (two) and lobus (lobe), which duly illustrate the specific shape of its leaf. Contemporary Ginkgo biloba L. plant based pharmaceuticals mostly comprise extracts recovered from leaves harvested during fall, when the concentration of active components reaches its peak. Recent investigations have managed to establish the chemical composition of the plant leaf, together with the mechanisms underlying its beneficial effects on rheological profile of the blood and acceleration of its flow. High price of these preparations and their vast popularity have soon become an incentive for counterfeiting Ginkgo biloba L. extracts and the release of bogus drugs comprising cheaper extracts coming from other plants. Namely, modern Ginkgo biloba L.-based medicinal products and food supplements comprise extracts recovered from the plant leaf that get to be standardized according to its key pharmacological active components, most often flavone glycosides (represented in the share of 22\%-27\%) and terpene trilactones (represented in the share of 6\%-7\%). The flavonoids that predominate such preparations and are most relevant from the pharmacological standpoint are quercetin, kaempferol and isorhamnetin, their total amount and mutual ratios, thereby being an unquestionable indicator of the extract authenticity. Therefore, most of the analyses aiming at verifying the authenticity of a given Ginkgo biloba L.-based product boil down to the analysis of these parameters. Counterfeiting involves partial or full replacement of the Ginkgo biloba L. extract (GBE) with a cheaper plant extract of a similar composition, the latter occasionally being enriched with an additional amount of flavonoids, most often quercetin, not
\end{abstract}

Correspondence to: Aleksandar Racz, University of Applied Health

Studies, Mlinarska 38, HR-10000 Zagreb, Croatia

E-mail: aracz@zvu.hr

Received May 3, 2018, accepted May 29, 2018 
originating from the Ginkgo biloba L. plant. The aim of this study was to verify the authenticity and quality of Ginkgo biloba L.-based products circulating on the Croatian market. To that effect, 10 samples of products produced by various manufacturers were analyzed in a certified laboratory. The parameters based on which the authenticity of the preparations was assessed were the shares of aglycones of typical ginkgo flavone glycosides, that is to say, quercetin, kaempferol and isorhamnetin, and mutual ratios of the established quantities of quercetin to kaempferol as the key clues to unmasking Ginkgo extracts counterfeiting. The amount of ginkgo flavone glycosides was established using high performance liquid chromatography. The analysis proved $80 \%$ of the samples analyzed to be conformant to the label statements as regards the total amount of flavone glycosides and their mutual ratios. In $20 \%$ of the samples, the ratio of quercetin to kaempferol deviated from normal values; on top of that, the presence of the phytoestrogen genistein, one of the components typically comprised by the Sophora japonica L. plant, was also proven, documenting counterfeiting of the GBE and its replacement by the Sophora japonica L. extracts in the samples under consideration. Due to the untrue label statements descriptive of these products, the information on the presence of pharmacologically active genistein was neglected to be mentioned despite its unfavorable health impact that can be expected in some consumer groups. The results of this study indicated the frequency of counterfeiting the Ginkgo biloba L.-based products found on the Croatian market to be deemed substantial. Therefore, a more rigorous and more thorough control of these products and sanctioning of irresponsible manufacturers and distributers is proposed, so as to contribute to a higher market representation of high-quality products, as well as to avoid health risks and downsize the rate of their counterfeiting.

Key words: Ginkgo biloba; Quercetin; Counterfeit drugs; Croatia

\section{Introduction}

Ginkgo biloba L. (family: Ginkgoaceae; class: Ginkgoatae) is the eldest plant growing on the planet Earth, its origin dating 250-260 million years back into the history of our planet ${ }^{1}$. Given that it does not show any botanical or taxonomic kindredness with other plant species currently inhabiting our planet, it is called a living fossil plant. The plant is grown virtually all over the world. The eldest data on therapeutic virtues of the Ginkgo biloba L. and its medicinal use can be found in the roughly 5000-year old Chinese Pharmacopeia. The plant represents an integral part and a common 'tool' of the traditional Chinese medicine that has been used throughout its history, in particular to the effect of alleviating asthma symptoms and cough, and to cure bronchitis and impotence.

Current analytical techniques have managed to establish chemical composition of the Ginkgo biloba $L$. plant and uncover some of the mechanisms underlying its impact on rheological profile of the blood and enhancement of its flow. These discoveries have contributed to an ever-growing use of the plant to the effect of health preservation and alleviation of various symptoms. The production of Ginkgo biloba L.-based preparations witnessed its rise following 1994, when the World Health Organization (WHO) and Federal Commission for Drug Monographs of the Federal
Republic of Germany (E Commission) released a Ginkgo biloba L. extract (GBE) devoted monograph bringing a positive review on it, which was taken as formal approval of the plant administration to the end of enhancing peripheral and cerebral blood flow ${ }^{1-3}$.

Among roughly 50 compounds isolated from the plant insofar, those most relevant for its biological activity are the following two groups of substances: flavonoids and terpene trilactones ${ }^{4}$. The composition of the plant is predominated by flavonoids, among which the most represented are flavonol mono-, di- and triglycosides having an ester bond with the $\mathrm{p}$-coumarin $\mathrm{acid}^{5}$. Aglyconic molecular parts of typical ginkgo flavone glycosides are quercetin, kaempferol and isorhamnetin ${ }^{6}$.

The terpene trilactone group, a unique component comprised by the Ginkgo biloba L. only, is represented by diterpene lactone ginkgolides $\mathrm{A}, \mathrm{B}, \mathrm{C}, \mathrm{J}$ and $\mathrm{M}$, and sesquiterpene lactone bilobalide ${ }^{7}$.

In nature, these unique compounds can be found solely in the Ginkgo biloba L. plant. Clinical trials have shown the administration of GBE to be justified as adjuvant therapy in a number of conditions including blood flow impairments ${ }^{8}$, impotence, migraine ${ }^{9}$, vitiligo $^{10}$, cardiac symptoms, eye impairments, neurasthenic complaints ${ }^{11}$, tinnitus ${ }^{12}$, chronic cerebral insufficiency ${ }^{13}$, forgetfulness ${ }^{14}$, depression, dementia ${ }^{15,16}$ and senile conditions ${ }^{17}$, blood preasure ${ }^{18}$ and Alzheimer's disease ${ }^{19}$. 
Therapeutic effects of this plant are attributed to the synergistic activity of all plant components. Still, certain acting mechanisms are attributed to particular groups of compounds; for instance, when it comes to the exchange of substances through vessel walls and vessel wall fragility, the most often tagged substances are ginkgo flavone glycosides ${ }^{20}$. On top of the abovementioned effects, these compounds manifest a high antioxidative activity because of which the Ginkgo biloba L. plant has a high capacity of binding free radicals $^{21,22}$.

Owing to binding and deactivation of oxygen radicals rich in energy, the plant also increases tissue tolerance to the lack of oxygen. It is also believed that some differences exist in the acting mechanisms of individual flavone derivatives. For instance, quercetin has a more profound impact on low-density lipoprotein (LDL)-cholesterol reduction ${ }^{23}$; on top of that, it exhibits vasodilating and antiviral effects ${ }^{24}$, and has been proven to act as an antihistamine drug 25 .

Kaempferol aids in the prevention of atherosclerosis owing to the inhibition of LDLs. It also inhibits platelet aggregation and development of malignant cells ${ }^{26}$.

Terpene trilactones are believed to be capable of inhibiting the platelet activation factor (PAF) that induces platelet aggregation, as well as the development of edemas, smooth muscle contractions, hypertension, bronchial constriction, increased microvascular permeability, increased hematocrit and lysosomal enzyme secretion $^{27,28}$.

Notwithstanding its favorable characteristics, attention should also be paid to the adverse effects of Ginkgo biloba L. in terms of its interactions with drugs of the anticoagulant class, as well as with other drugs preventing platelet aggregation, making the concomitant use of the two contraindicated. Of note, ginkgolic acid can also exhibit harmful effects, so its concentration in a standardized extract should not go beyond 5 $\mathrm{mg} / \mathrm{kg}^{29}$.

An incentive for designing a vast number of Ginkgo biloba L.-based food supplements was a marked biological activity related to the plant. Therefore, the plant can be found in such products in various shares. GBE has grown to become an integral part of herbal medicinal products, food supplements, cosmetic and borderline (cosmetic/medicinal) products ${ }^{30}$.

In order to achieve the expected biological activity, it is absolutely essential for a product to have a well- balanced, natural and reliable composition of extracts; in the light of the foregoing, the rise in the demand for GBE-based products has made GBE standardization imperative. A standardized dry GBE is obtained by virtue of extraction from the ginkgo leaf using a solvent (acetone and water). In the subsequent course, the extract should be cleansed of not only solvent, but also of the ginkgolic acid that may induce an allergic response, let alone toxic effects should it be present in higher quantities. Standardization of purified GBE most often aims at $24 \%$ representation of ginkgo flavone glycosides and 6\% representation of terpene lactones ${ }^{31}$. Specifications stated by the manufacturer of a standardized GBE should reveal the percent-shares of the above substances, with the same piece of information advertised on the product label.

Verification of genuineness and quality of GBE and GBE-based products relies on the analysis of GBE key components falling into the groups of flavonoids and terpene trilactones.

High demand, high price and an ever-growing supply have unanimously affected the frequency of counterfeiting that involves either partial or full replacement of GBE with a cheaper plant extract similar in composition. In order to harmonize the total amount of ginkgo flavone glycosides comprised by counterfeit drugs with the GBE standards and labeled values, the extract gets to be enriched by an additional amount of flavonoids not coming from the Ginkgo biloba L. plant. To the above effect, quercetin, i.e. its glycoside form rutin, is exploited. The latter represents one of the most common flavonoids that, among other, can be isolated from buckwheat (Fagopyrum esculentum Moench), elder flower (Sambucus nigra L.), herb-ofgrace (Ruta graveolens L.), citruses and other plants, fruit and vegetables ${ }^{32-34}$.

By virtue of these interventions, the total amount of flavone glycosides present in fake drugs and the amount present in an original GBE are usually equalized but their mutual ratios, which, besides their percent-shares, pose as the key criteria guiding the verification of GBE genuineness or counterfeiting disclosure, witness changes. Based on the available literature, the ratio of quercetin to kaempferol to isorhamnetin should be $5: 5: 1$ on average.

The indicator of particular relevance for unmasking possible counterfeiting is the quercetin to kaempferol $(\mathrm{Q} / \mathrm{K})$ ratio that should approximate 1 , but can also fall within a somewhat wider range of 0.8-1.65. 
Given that the extract whose percent-share of flavone glycosides has been deliberately adjusted by virtue of quercetin addition comprises a due amount of flavone glycosides, the products harboring such an extract can be mistaken for genuine if controlled in an inappropriate manner. Therefore, unmasking the potential fraud equally calls for appropriate choice of an analytical procedure and appropriate interpretation of the results obtained. Lately, the analyses of target products have ever more often revealed a substantially higher share of kaempferol in such preparations, suggesting possible counterfeiting in terms of GBE replacement by an extract of the Chinese plant termed Sophora japonica L. (Fructus sophorae), which comprises ten-fold higher amounts of kaempferol than Ginkgo biloba L. However, apart from harboring high amounts of quercetin and kaempferol, the plant in reference also comprises a phytoestrogen falling into the group of isoflavones and termed genistein. The latter has a marked pharmacological activity and acts similar to estrogen hormones; therefore, its presence should be advertised on product labels. Due to an ever more frequent use of the Sophora japonica L. extract as a replacement for GBE, analyses aiming at detecting the genistein presence in GBE-based products have been proposed, positive outcomes thereby being considered as counterfeiting markers.

Verification of genuineness and quality of GBE and GBE-based products relies on the analysis of its key components falling into the groups of flavonoids and terpene trilactones. The compounds most often determined within the frames of these analyses are ginkgo flavone glycosides, while terpene trilactones analyses, although important for comprehensive verification of analyzed samples, are still less frequently represented in routine protocols.

The majority of techniques used for ginkgo flavone glycoside determination resort to high performance liquid chromatography (HPLC). Two most commonly implemented and internationally acknowledged techniques are the technique stipulated under the European (and Croatian) Pharmacopoeia and the AOAC 2006.07 technique.

The above techniques allow for determination of shares and mutual ratios of the three major flavonoids, that is, quercetin $(\mathrm{Q})$, kaempferol $(\mathrm{K})$ and isorhamnetin (I), the pertaining calculations thereby making use of conversion into their glycoside forms.
Given that products comprising the extract of the Ginkgo biloba L. plant are among the most often counterfeited plant-based food supplements, it is of paramount importance to control these products using techniques that allow for establishment of individual representation and mutual ratios of the three substances listed above in a given product.

Controlling counterfeit products is as important today if not even more important than controlling the products and raw materials from secondary pollution as a consequence of inappropriate production or storage and storage of raw materials, especially in connection with the increasing pollution of plant and products with different types of heavy metals ${ }^{35}$ or mycotoxins $^{36}$ and possible adverse health effects.

\section{Aim}

This study aimed at verifying the quality, safety and accuracy of information labeled on GBEs and GBE-based food supplements available on the Croatian market. The above parameters are essential for safe administration of these preparations and for gaining consumer trust, since only high-quality natural products comprising due shares of active substances are capable of achieving the anticipated and rightfully expected biological effects.

Within the frame of the study, 10 types of Ginkgo biloba L.-based products circulating on the market, including two GBEs and eight food supplements (formulated as capsules, tablets or powder) were analyzed in the laboratories of the Croatian Institute of Public Health. The study goal was to uncover the possible counterfeit drugs comprising ingredients potentially jeopardizing patient/consumer health or misleading the patients/consumers using them.

\section{Materials and Methods}

Representative samples of GBE-based products, delivered to the test laboratory in undamaged packaging and sampled to the effect of unmasking possible counterfeiting, i.e. false labeling, were analyzed. In total, 10 types of products were analyzed, including two GBEs and eight Ginkgo biloba L.-based food supplements.

To the above end, the AOAC 2006.07 technique $^{6}$ that relies on determination of shares of the flavone aglycones quercetin, kaempferol and isorhamnetin was used. The study made use of a Shimadzu HPLC sys- 
tem and the pertaining CLASS-VP Software, a Photo Diode Array detector and Supelcosil LC-18 (4.6x250 $\mathrm{mm}$ ) column, the mobile phase thereby being represented by $0.85 \%$-phosphoric acid:methanol (1:1 v/v).

The total concentration of flavone glycosides was calculated as the sum of individual concentrations of three flavone glycosides at the $370 \mathrm{~nm}$ wavelength. Wavelength was modified to $270 \mathrm{~nm}$ because of better visibility $\mathrm{L}$, as shown in all chromatograms. The purity of quercetin dihydrate (i.e. molecular water; 302/338= 0.893), kaempferol and isorhamnetin [substance $(\mathrm{mg})$ $\mathrm{x}$ purity $=$ substance $(\mathrm{mg})$ ] was also taken into account. The obtained aglycone shares were then multiplied by the conversion factor used for calculation of the correspondent glycoside forms.

Flavone glycosides of the three aglycones were established as percent-shares of individual glycosides using either the equation:

$\%$ of an individual glycoside $(\% \mathrm{~m} / \mathrm{m})=(\mathrm{C} \times \mathrm{FV} \times$ F x 100)/W), where:

- C stands for the concentration of aglycones $(\mathrm{mg} / \mathrm{mL})$ calculated from the calibration curve;

- FV stands for the final volume;

- F stands for the aglycone conversion factor; and

- W stands for the mass proportion of the tested sample (mg); or as individual glycosides comprised by a single capsule or tablet using the equation:

$2 \%$ of a given glycoside/tablet $(\mathrm{mg})=((\mathrm{C} \times \mathrm{FV} \times \mathrm{F}$ $\mathrm{x}$ 100)/W) x T, where:

- C stands for the concentration of aglycones $(\mathrm{mg} / \mathrm{mL})$ calculated from the calibration curve;

- FV stands for the final volume;

- F stands for the aglycone conversion factor;

- W stands for mass proportion of the tested sample (mg); and

- T stands for the average tablet/capsule mass (mg)

The following conversion factors were applied: quercetin, 2.504; kaempferol, 2.588; and isorhamnetin, 2.437 .

\section{Results}

Within the study frame, a total of 10 representative samples (2 GBEs and 8 food supplements) delivered to the test lab in undamaged packages were analyzed.

The GBE standard prepared from the reference substances in terms of quercetin, kaempferol and isorhamnetin was used for plotting a control chart based on which these aglycones, expressed in their glycoside forms, were identified in tested samples (Figs. 1-15).

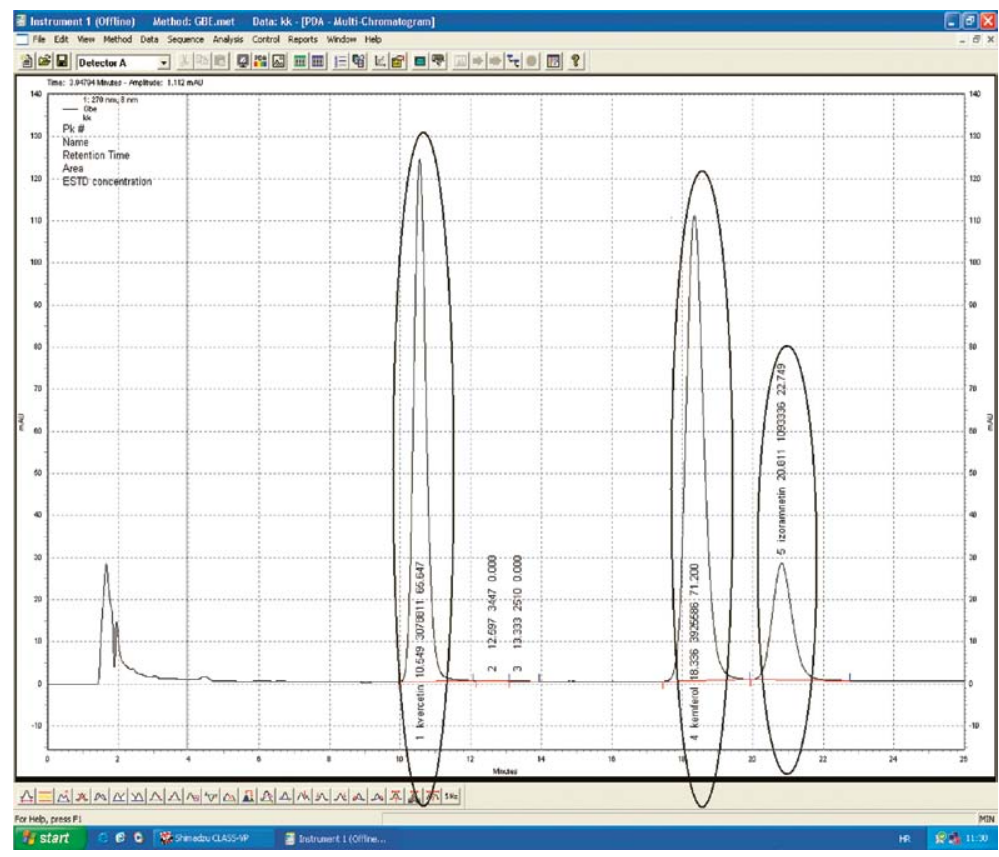

Fig. 1. Chromatogram of the standard used for plotting a GBE flavonoid control chart. 
Sample No 1 - coated tablets; labeled information: $80 \mathrm{mg}$ of GBE in two coated tablets; recommended dosage: 1 coated tablet $2 \mathrm{x} /$ day

The total amount of ginkgo flavone glycosides constituting sample No 1, expressed per two coated tablets (i.e. per daily recommended dose) equaled $6.17 \mathrm{mg}$. The amount of GBE having $7 \%$ of ginkgo flavone glycosides (as advertised on the label) comprised by two coated tablets equaled $87.64 \mathrm{mg}$, while the quercetin/kaempferol ratio equaled 1.0.

The results displayed below also bring information on the quantity of each ginkgo flavone glycoside under study and on the pertaining measurement uncertainty, as follows:

quercetin $=(3625 \pm 207) \mathrm{mg} / \mathrm{kg}$

kaempferol $=(3611 \pm 224) \mathrm{mg} / \mathrm{kg}$

isorhamnetin $=(479 \pm 90) \mathrm{mg} / \mathrm{kg}$
$\mathrm{K}=3$; confidence level: roughly $99 \%$

$\mathrm{K}=3$; confidence level: roughly $99 \%$

$\mathrm{K}=3$; confidence level: roughly $99 \%$

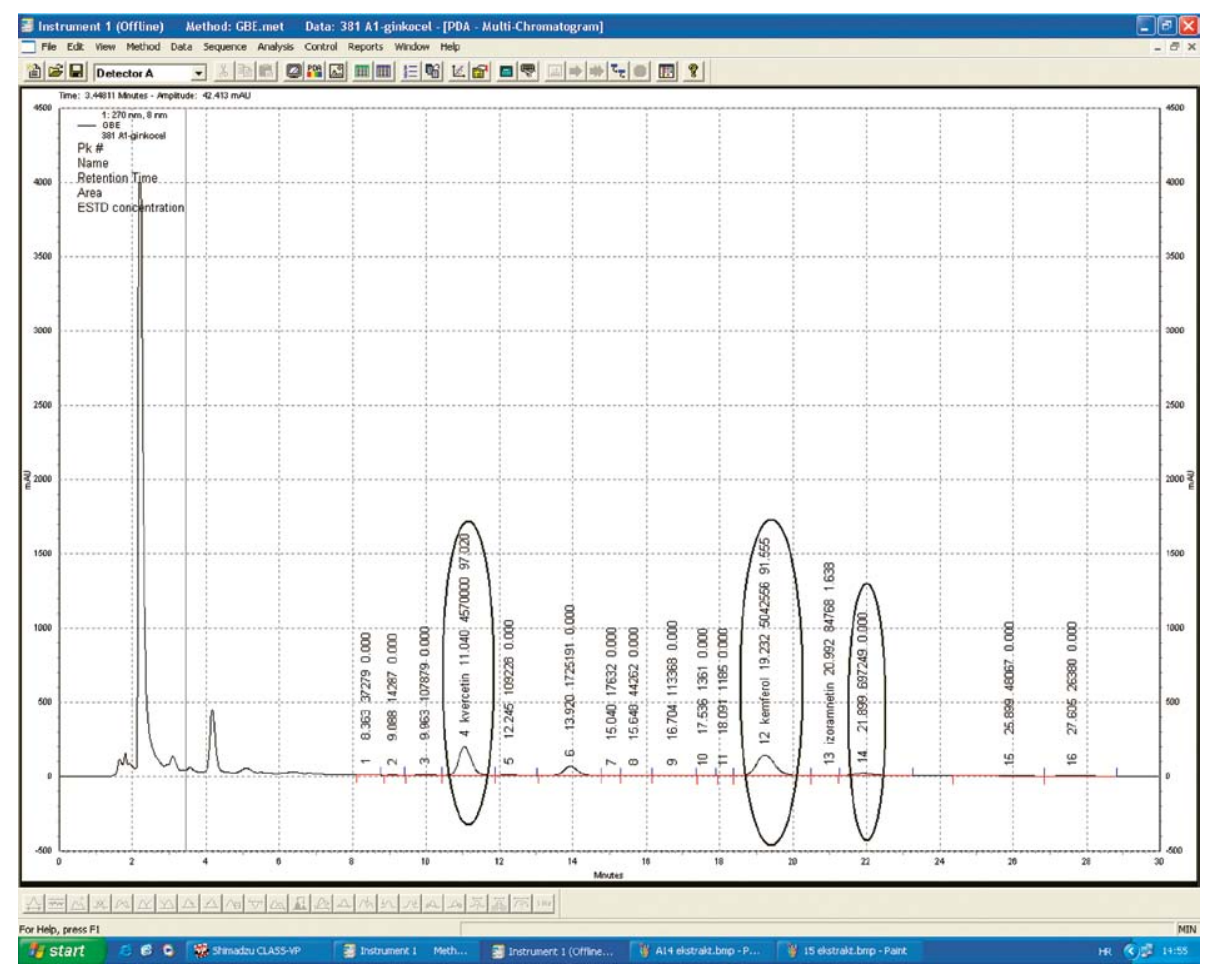

Fig. 2. Chromatogram of sample No 1. 
Sample No 2 - capsules, labeled information: $60 \mathrm{mg}$ of GBE in a single capsule; recommended dosage: one capsule/day

The total amount of ginkgo flavone glycosides constituting sample No 2, comprised by a single capsule, equaled $14.52 \mathrm{mg}$, while the amount of GBE having 24\% of ginkgo flavone glycosides (as advertised on the label) comprised by a single capsule equaled $60.5 \mathrm{mg}$, the quercetin/kaempferol ratio thereby being 1.03 .

The results displayed below also bring information on the quantity of each ginkgo flavone glycoside under study and on the pertaining measurement uncertainty, as follows:

quercetin $=(22802 \pm 1230) \mathrm{mg} / \mathrm{kg} \quad \mathrm{K}=3$; confidence level: roughly $99 \%$

kaempferol $=(22174 \pm 1375) \mathrm{mg} / \mathrm{kg} \quad \mathrm{K}=3$; confidence level: roughly $99 \%$

isorhamnetin $=(1858 \pm 349) \mathrm{mg} / \mathrm{kg} \quad \mathrm{K}=3$; confidence level: roughly $99 \%$

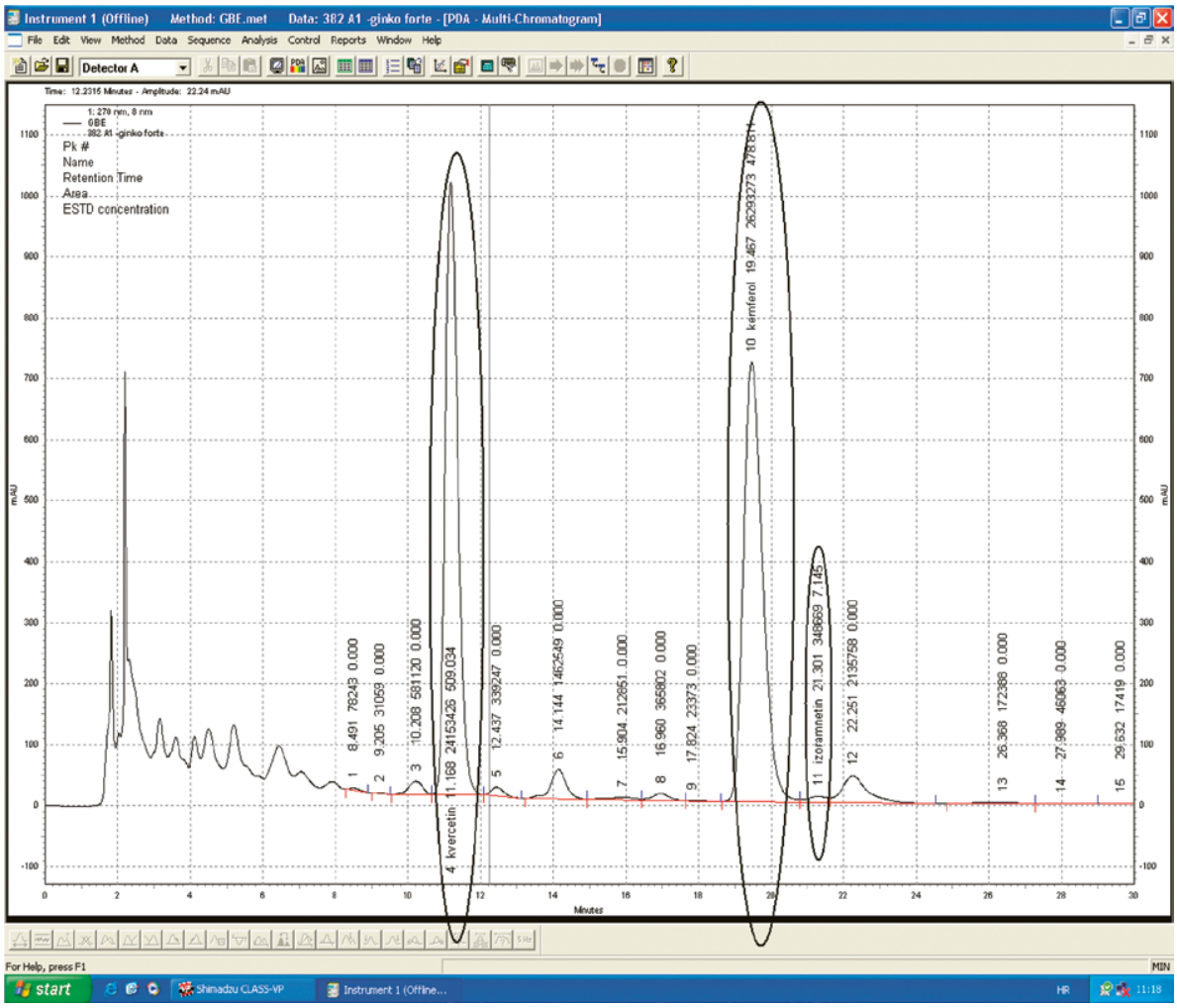

Fig. 3. Chromatogram of sample No 2. 


\section{Sample No 3 - capsules; labeled information: $40 \mathrm{mg}$ of GBE; recommended dosage: two tablets 1x/day}

The total amount of ginkgo flavone glycosides constituting sample No 3, comprised by a single capsule, equaled $9.23 \mathrm{mg}$, while the amount of GBE having $24 \%$ of ginkgo flavone glycosides (as advertised on the label) equaled $380.5 \mathrm{mg}$, the quercetin/kaempferol ratio thereby being 1.17 .

The results displayed below also bring information on the quantity of each ginkgo flavone glycoside under study and on the pertaining measurement uncertainty, as follows:

quercetin $=(14117 \pm 805) \mathrm{mg} / \mathrm{kg}$

kaempferol $=(12031 \pm 746) \mathrm{mg} / \mathrm{kg}$

isorhamnetin $=(1827 \pm 343) \mathrm{mg} / \mathrm{kg}$
$\mathrm{K}=3$; confidence level: roughly $99 \%$

$\mathrm{K}=3$; confidence level: roughly $99 \%$

$\mathrm{K}=3$; confidence level: roughly $99 \%$

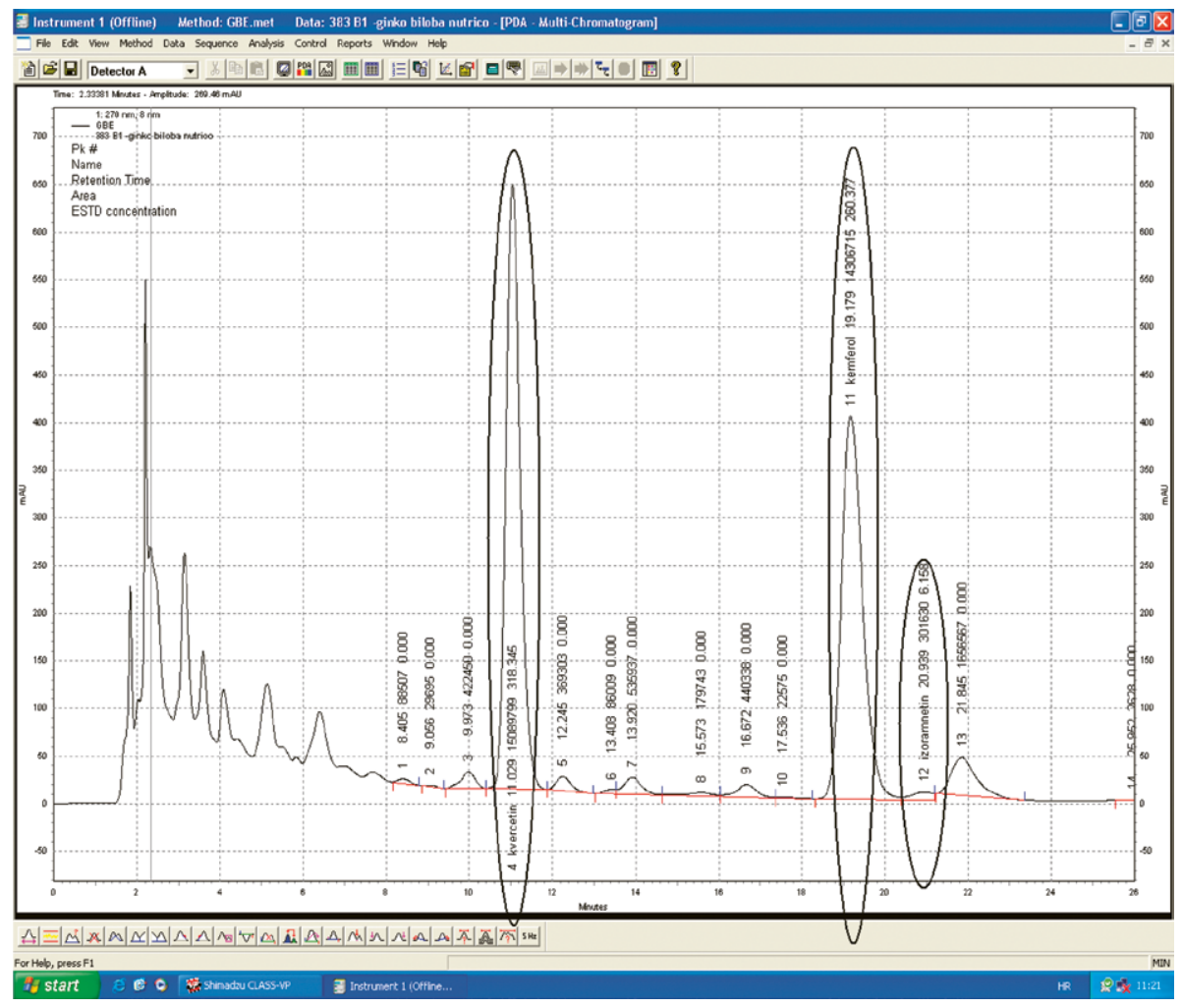

Fig. 4. Chromatogram of sample No 3. 
Sample No 4 - gelatine-coated capsules; labeled information: $60 \mathrm{mg}$ of GBE in a single capsule; recommended dosage: one capsule/day

The total amount of ginkgo flavone glycosides constituting sample No 4, comprised by a single gelatinecoated capsule, equaled $14.03 \mathrm{mg}$, while the amount of GBE having 24\% of ginkgo flavone glycosides (as advertised on the label) comprised by a single gelatine-coated capsule equaled $58.4 \mathrm{mg}$, the quercetin/kaempferol ratio thereby being 1.04 .

The results displayed below also bring information on the quantity of each ginkgo flavone glycoside under study and on the pertaining measurement uncertainty, as follows:

quercetin $=(9460 \pm 539) \mathrm{mg} / \mathrm{kg}$

$\mathrm{kaempferol}=(9057 \pm 562) \mathrm{mg} / \mathrm{kg}$

isorhamnetin $=(1520 \pm 286) \mathrm{mg} / \mathrm{kg}$
$\mathrm{K}=3$; confidence level: roughly $99 \%$

$\mathrm{K}=3$; confidence level: roughly $99 \%$

$\mathrm{K}=3$; confidence level: roughly $99 \%$

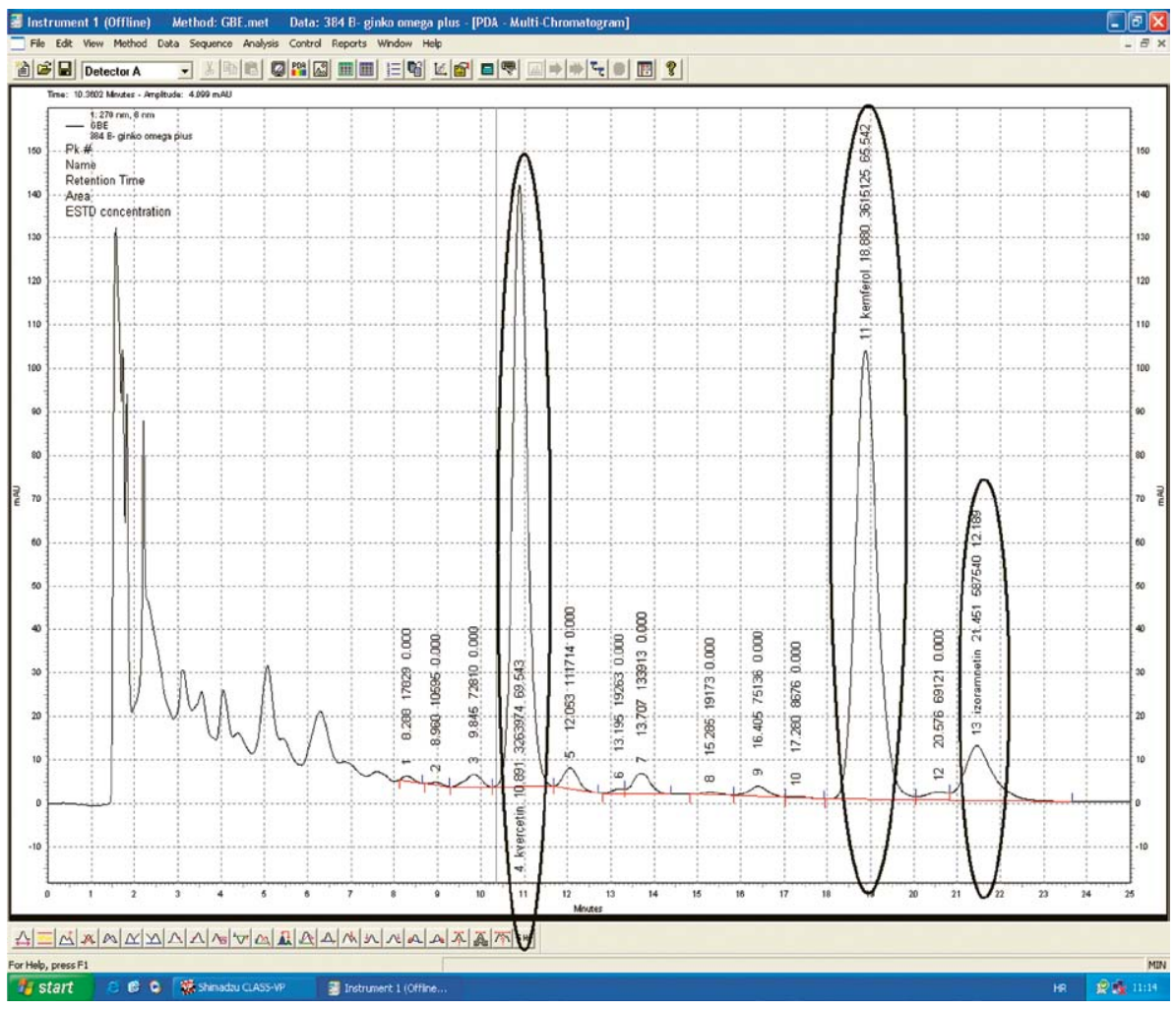

Fig. 5. Chromatogram of sample No 4. 
Sample No 5 - gelatine-coated capsules, labeled information: $60 \mathrm{mg}$ of GBE in a single gelatine-coated capsule; recommended dosage: one capsule/day

The total amount of ginkgo flavone glycosides constituting sample No 5, comprised by a single gelatinecoated capsule $(660 \mathrm{mg})$, equaled $14.11 \mathrm{mg}$, while the amount of GBE having 24\% of ginkgo flavone glycosides (as advertised on the label) comprised by a single gelatine-coated capsule equaled $58.80 \mathrm{mg}$, the quercetin/ kaempferol ratio thereby being 1.06 .

The results displayed below also bring information on the quantity of each ginkgo flavone glycoside under study and on the pertaining measurement uncertainty, as follows:

quercetin $=(9337 \pm 532) \mathrm{mg} / \mathrm{kg}$

kaempferol $=(8402 \pm 521) \mathrm{mg} / \mathrm{kg}$

isorhamnetin $=(1077 \pm 202) \mathrm{mg} / \mathrm{kg}$
$\mathrm{K}=3$; confidence level: roughly $99 \%$

$\mathrm{K}=3$; confidence level: roughly $99 \%$

$\mathrm{K}=3$; confidence level: roughly $99 \%$

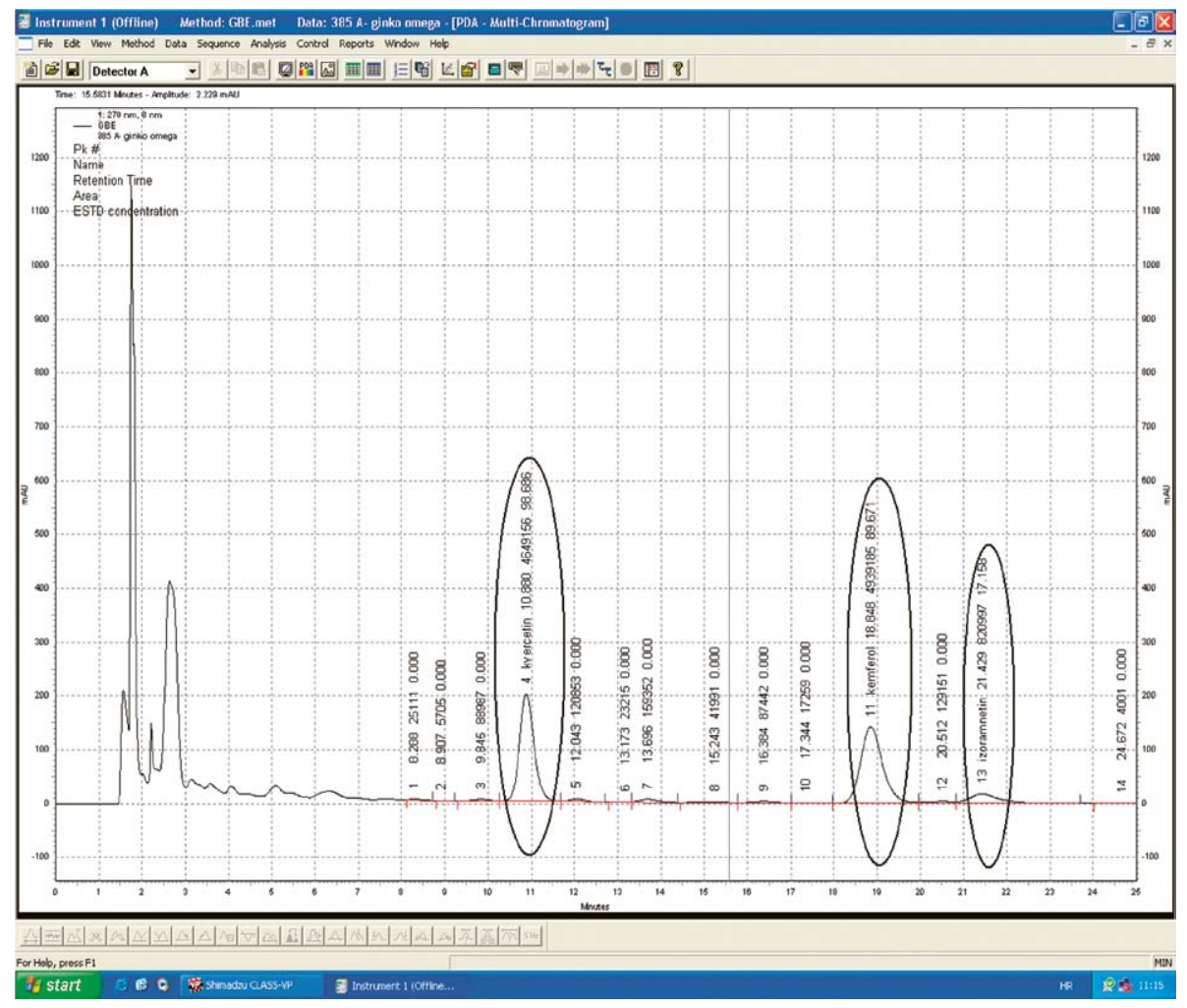

Fig. 6. Chromatogram of sample No 5. 
Sample No 6 - coated tablets; labeled information: $80 \mathrm{mg}$ in a single coated tablet; recommended dosage: one coated tablet/day

The total amount of ginkgo flavone glycosides comprised by two coated tablets equaled $5.78 \mathrm{mg}$, while the amount of GBE having $24 \%$ of ginkgo flavone glycosides (as advertised on the label) comprised by a single coated tablet equaled $82.6 \mathrm{mg}$, the quercetin/kaempferol ratio thereby being 0.99 .

The results displayed below also bring information on the quantity of each ginkgo flavone glycoside under study and on the pertaining measurement uncertainty, as follows

$\begin{array}{ll}\text { quercetin }=(3331 \pm 190) \mathrm{mg} / \mathrm{kg} & \mathrm{K}=3 \text {; confidence level: roughly } 99 \% \\ \text { kaempferol }=(3363 \pm 208) \mathrm{mg} / \mathrm{kg} & \mathrm{K}=3 ; \text { confidence level: roughly } 99 \% \\ \text { isorhamnetin }=(680 \pm 128) \mathrm{mg} / \mathrm{kg} & \mathrm{K}=3 \text {; confidence level: roughly } 99 \%\end{array}$

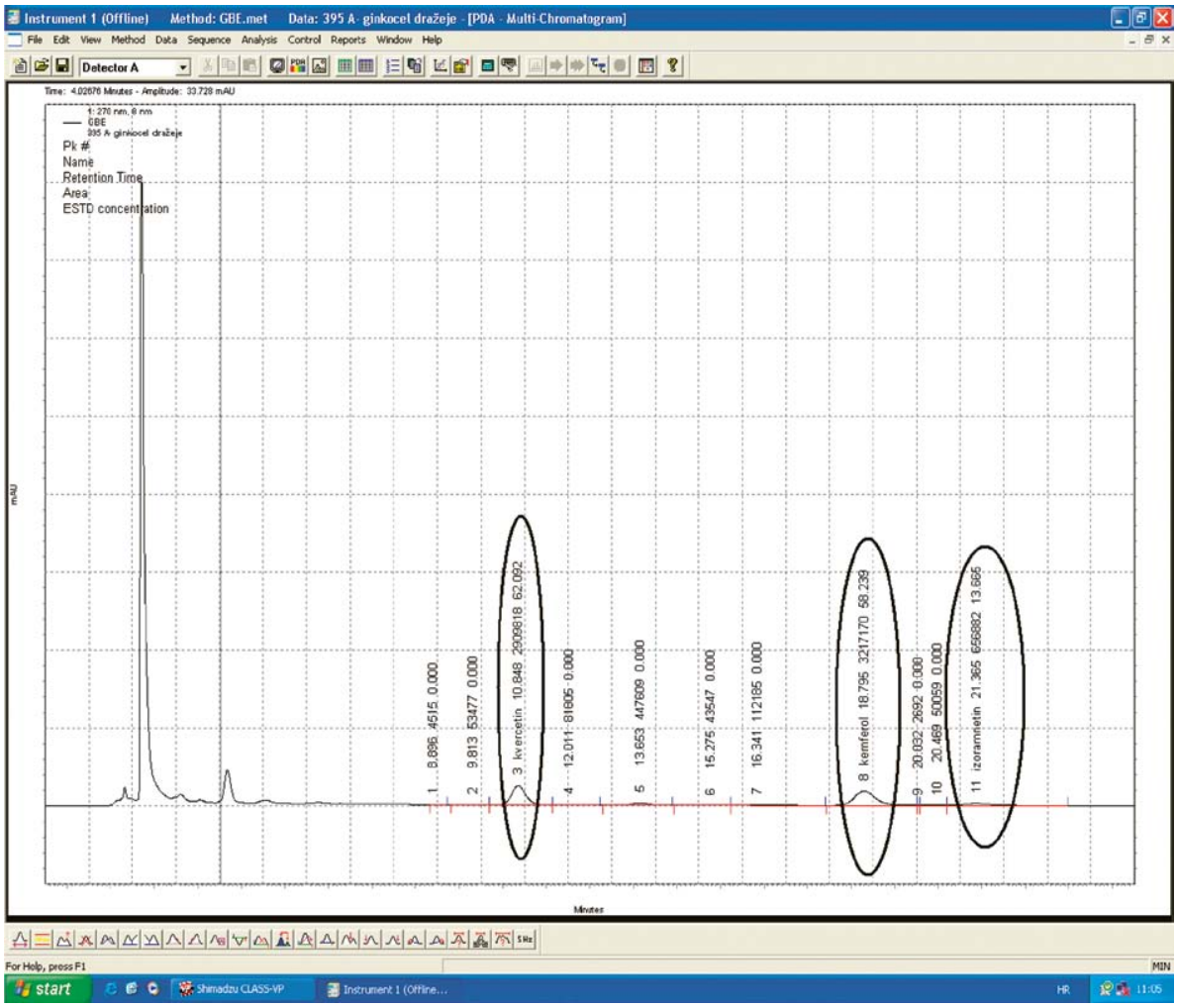

Fig. 7. Chromatogram of sample No 6. 
Sample No 7 - capsules; labeled information: $60 \mathrm{mg} \mathrm{GBE}$ in a single capsule; recommended daily dosage: one capsule

The total amount of ginkgo flavone glycosides comprised by a single capsule (660 mg) equaled $14.1 \mathrm{mg}$, while the amount of GBE having $24 \%$ of ginkgo flavone glycosides (as advertised on the label) comprised by a single capsule equaled $58.7 \mathrm{mg}$, the quercetin/kaempferol ratio thereby being 0.84 .

The results displayed below also bring information on the quantity of each ginkgo flavone glycoside under study and on the pertaining measurement uncertainty, as follows:

$\begin{array}{ll}\text { quercetin }=(9389 \pm 535) \mathrm{mg} / \mathrm{kg} & \mathrm{K}=3 \text {; confidence level: roughly } 99 \% \\ \text { kaempferol }=(11196 \pm 694) \mathrm{mg} / \mathrm{kg} & \mathrm{K}=3 \text {; confidence level: roughly } 99 \% \\ \text { isorhamnetin }=(745 \pm 140) \mathrm{mg} / \mathrm{kg} & \mathrm{K}=3 \text {; confidence level: roughly } 99 \%\end{array}$

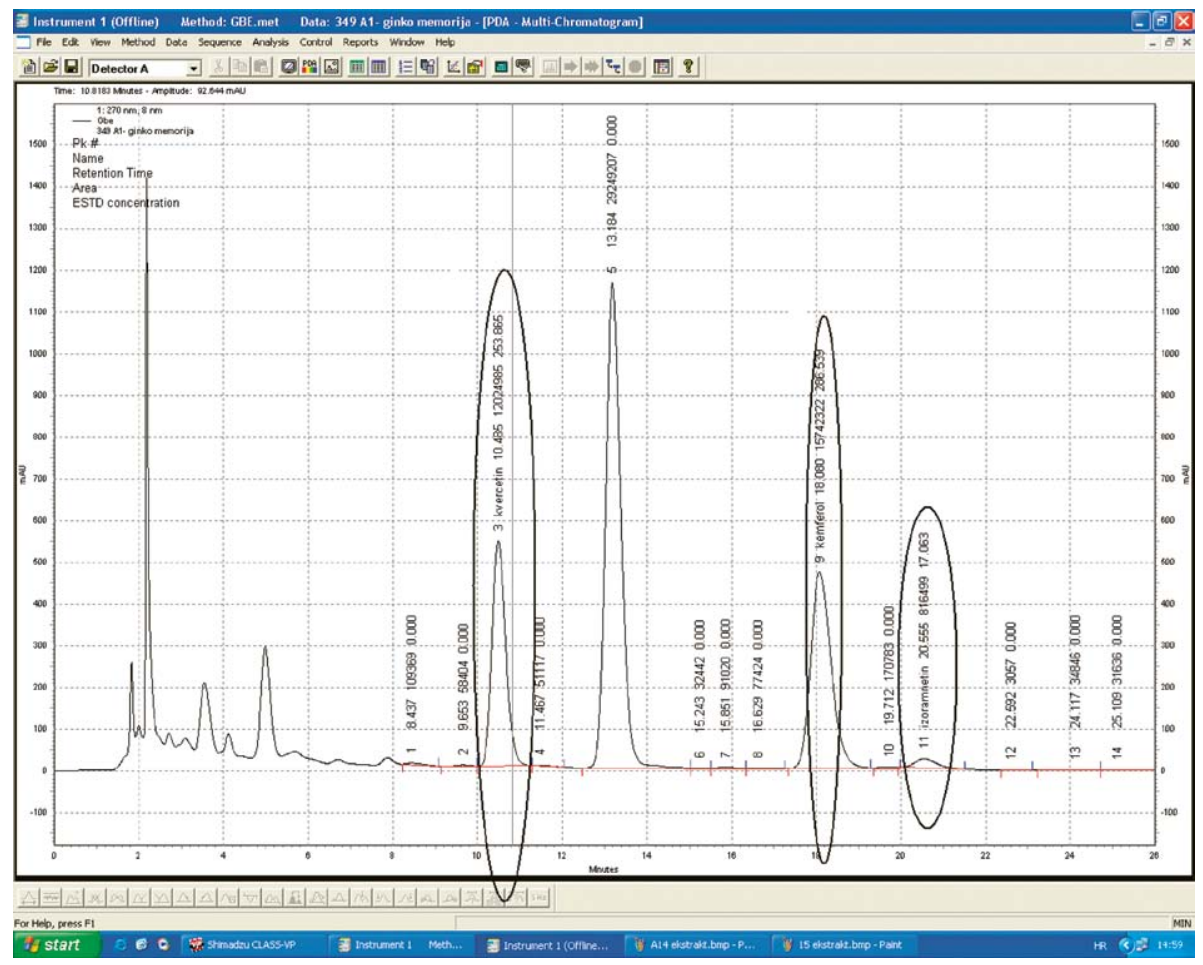

Fig. 8. Chromatogram of sample No 7. 
Sample No 8 - capsules; labeled information: $40 \mathrm{mg} \mathrm{GBE}$ in a single capsule; recommended daily dosage: one capsule

The total amount of ginkgo flavone glycosides constituting sample No 8, comprised by a single capsule (660 $\mathrm{mg}$ ), equaled $9.34 \mathrm{mg}$, while the amount of GBE having 24\% of ginkgo flavone glycosides (as advertised on the label) comprised by a single capsule equaled $38.95 \mathrm{mg}$, the quercetin/kaempferol ratio thereby being 1.03 .

The results displayed below also bring information on the quantity of each ginkgo flavone glycoside under study and on the pertaining measurement uncertainty, as follows:

quercetin $=(21844 \pm 1245) \mathrm{mg} / \mathrm{kg} \quad \mathrm{K}=3$; confidence level: roughly $99 \%$

kaempferol $=(21555 \pm 1318) \mathrm{mg} / \mathrm{kg} \quad \mathrm{K}=3$; confidence level: roughly $99 \%$

isorhamnetin $=(3615 \pm 680) \mathrm{mg} / \mathrm{kg} \quad \mathrm{K}=3$; confidence level: roughly $99 \%$

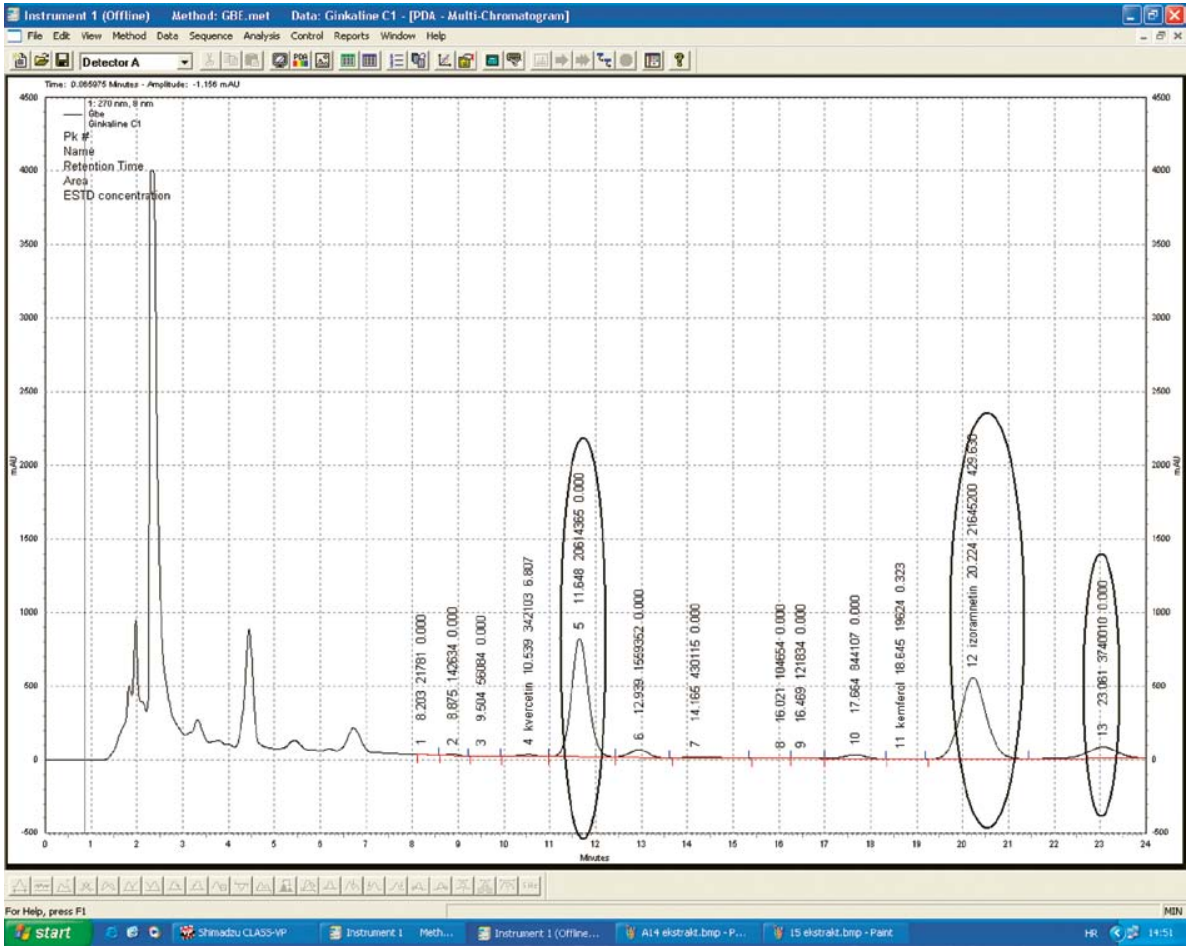

Fig. 9. Chromatogram of sample No 8. 


\section{Sample No 9 - dry Ginkgo biloba L. leaf extract}

The established percent-share of ginkgo flavone glycosides equaled 23.3\%, with the quercetin/kaempferol ratio of 1.09 .

The results displayed below also bring information on the quantity of each ginkgo flavone glycoside under study and on the pertaining measurement uncertainty, as follows:

quercetin $=(117255 \pm 6684) \mathrm{mg} / \mathrm{kg} \quad \mathrm{K}=3$; confidence level: roughly $99 \%$

kaempferol $=(107279 \pm 6651) \mathrm{mg} / \mathrm{kg} \quad \mathrm{K}=3$; confidence level: roughly $99 \%$

isorhamnetin $=(8483 \pm 1595) \mathrm{mg} / \mathrm{kg} \quad \mathrm{K}=3$; confidence level: roughly $99 \%$

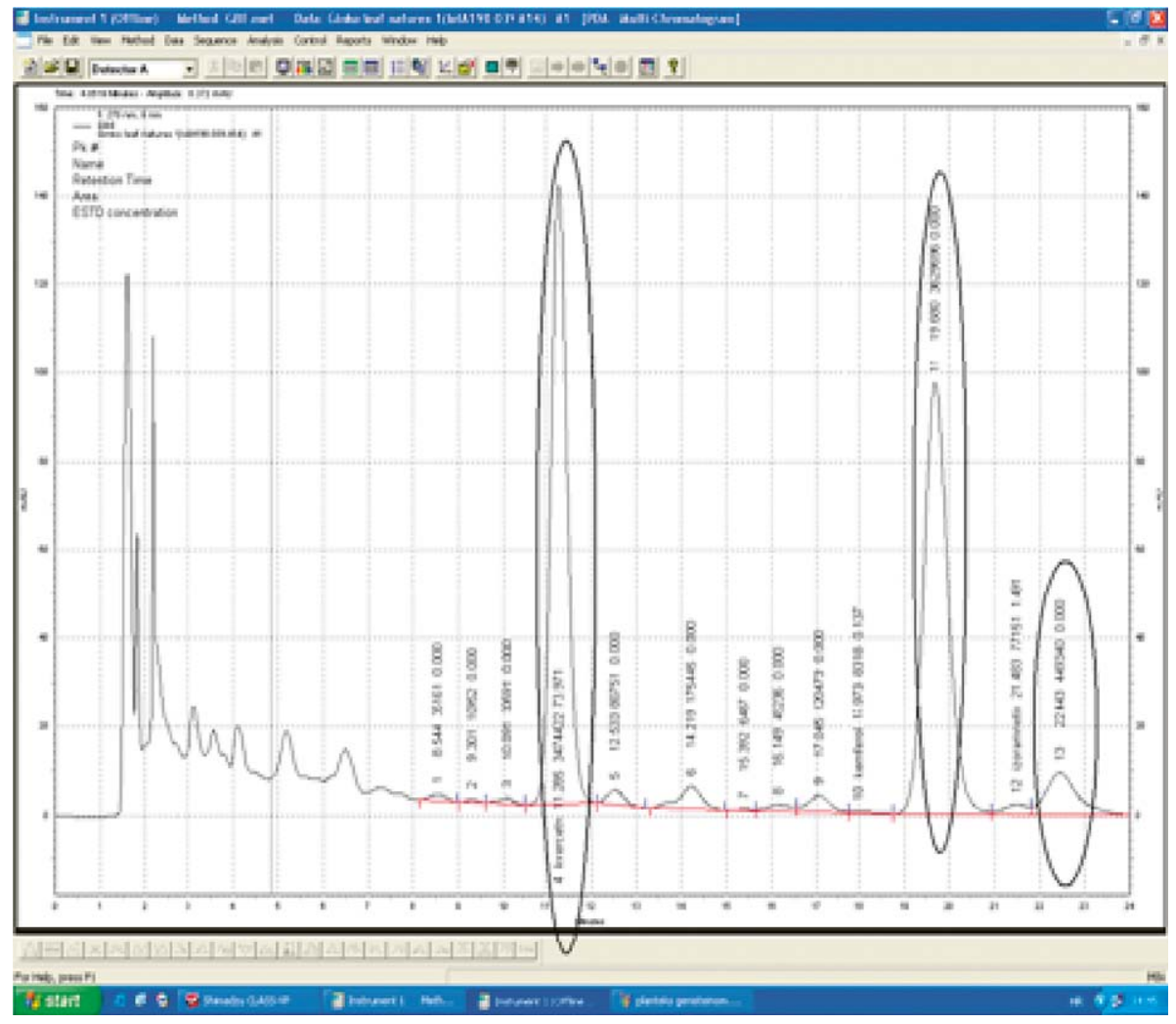

Fig. 10. Chromatogram of sample No 9. 


\section{Sample No 10 - dry Ginkgo biloba L. leaf extract}

The established percent-share of ginkgo flavone glycosides equaled $25.52 \%$, with the quercetin/kaempferol ratio of 0.83 .

The results displayed below also bring information on the quantity of each ginkgo flavone glycoside under study and on the pertaining measurement uncertainty, as follows:

quercetin $=(112448 \pm 6410) \mathrm{mg} / \mathrm{kg} \quad \mathrm{K}=3$; confidence level: roughly $99 \%$

kaempferol $=(135030 \pm 8372) \mathrm{mg} / \mathrm{kg} \quad \mathrm{K}=3$; confidence level: roughly $99 \%$

isorhamnetin $=(7708 \pm 1449) \mathrm{mg} / \mathrm{kg} \quad \mathrm{K}=3$; confidence level: roughly $99 \%$

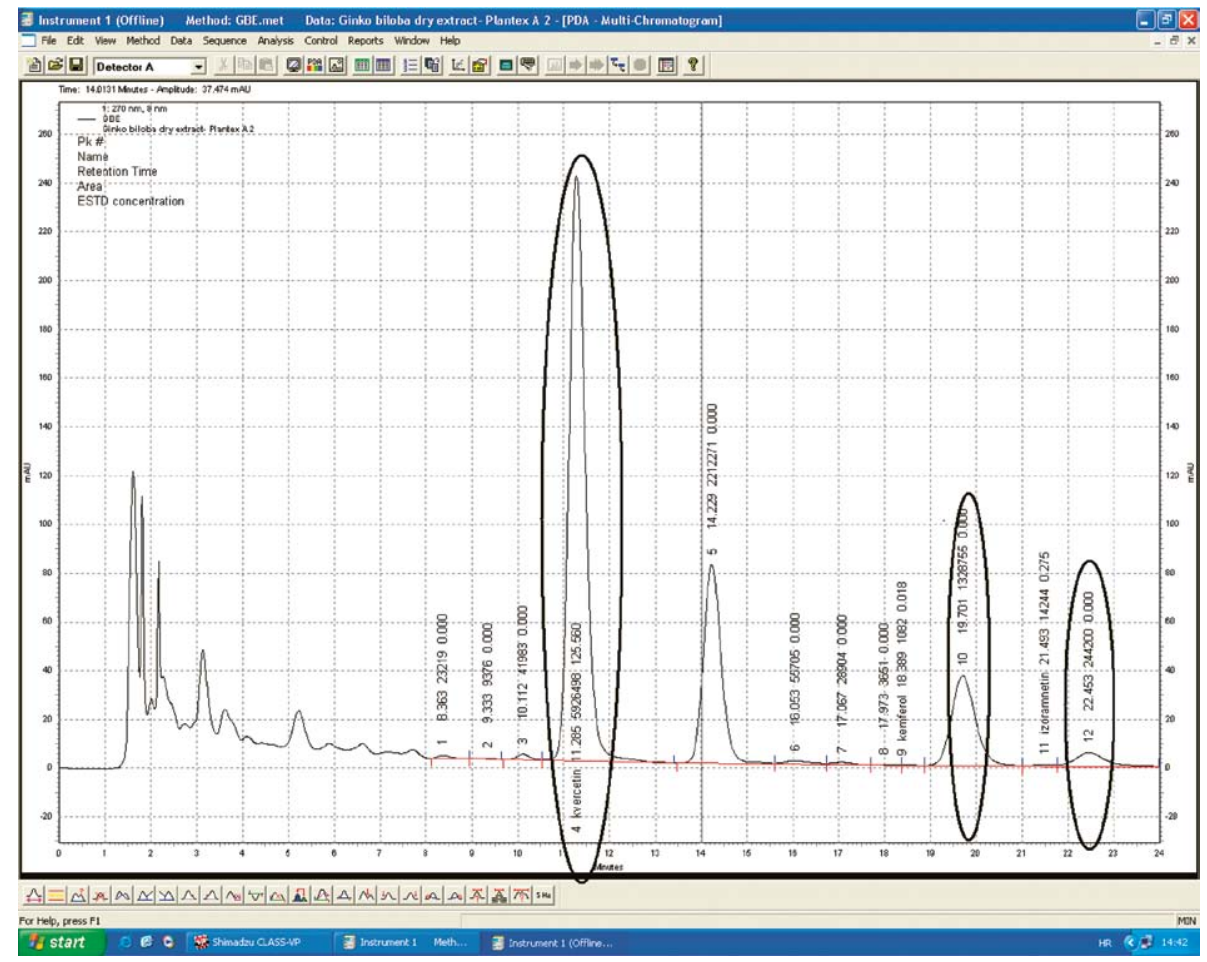

Fig. 11. Chromatogram of sample No 10. 
Based on the results obtained and chromatograms of the 10 samples analyzed, it was concluded that the samples No 1, 2, 3, 4, 5, 6, 8 and 9 fully complied with the labeled information on the total amount of ginkgo flavone glycosides and their mutual ratios.

However, the quercetin to kaempferol ratios established in samples No 7 and No 10 (0.83 and 0.84, respectively) were at the lower limit as compared with the $\mathrm{Q} / \mathrm{K}$ reference values published for the standardized Ginkgo biloba L. leaf extract in the literature sources (0.8-1.65). In both samples, there also was an unusual peak not seen on chromatographs descriptive of other samples. The assumption that the peak in question arose due to the presence of genistein was confirmed by virtue of additional analyses made by use of the genistein standard.

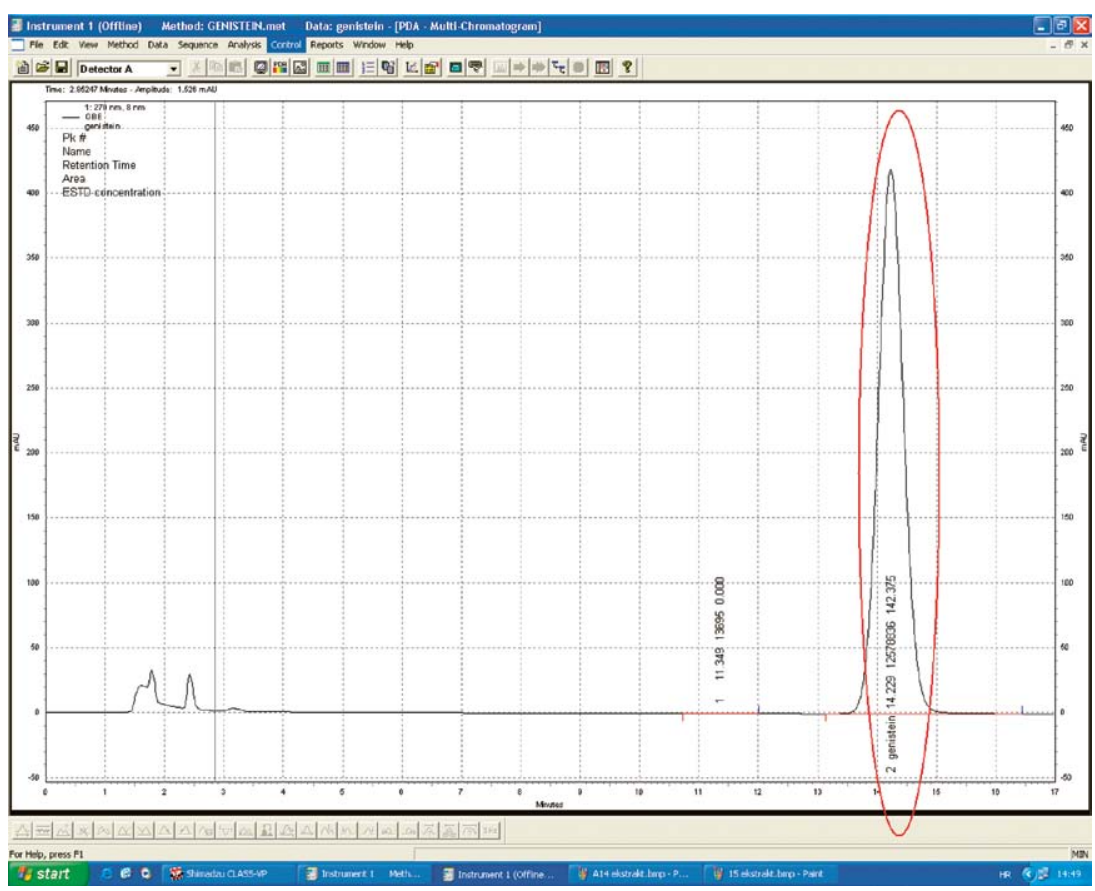

Fig. 12. Chromatogram of the reference genistein standard.

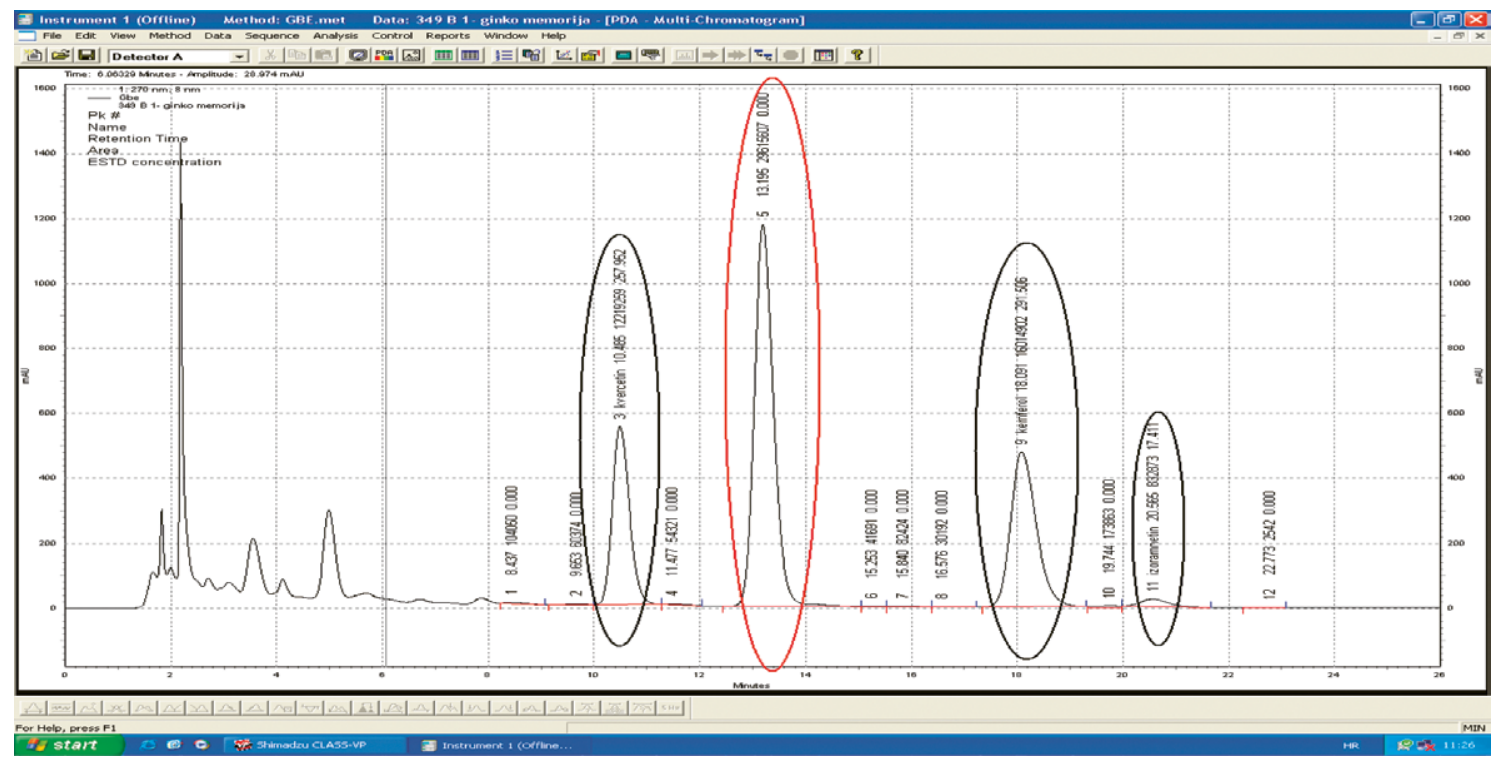

Fig. 13. Chromatogram of sample No 7 with a visible genistein peak. 


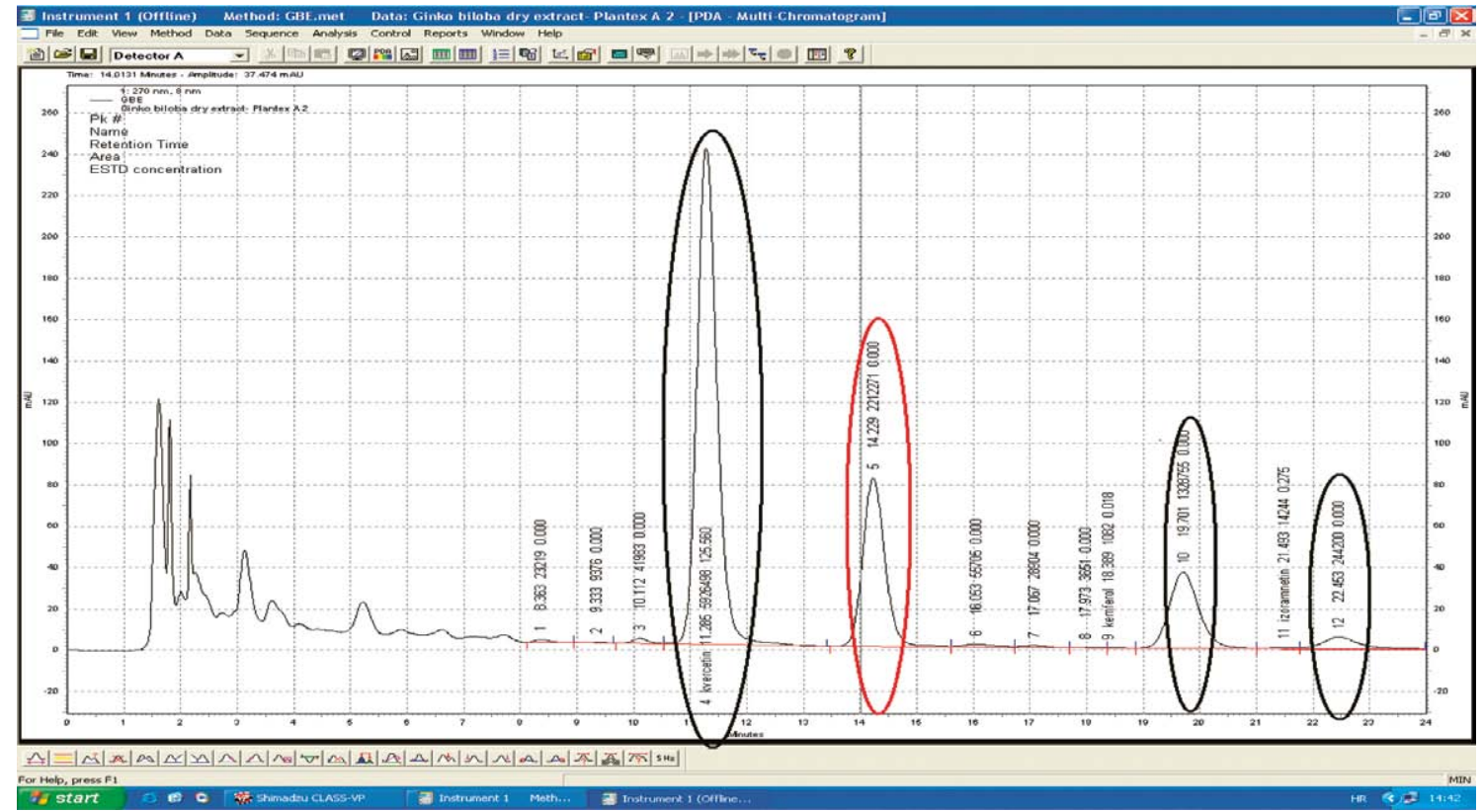

Fig. 14. Chromatogram of sample No 10 with a visible genistein peak.

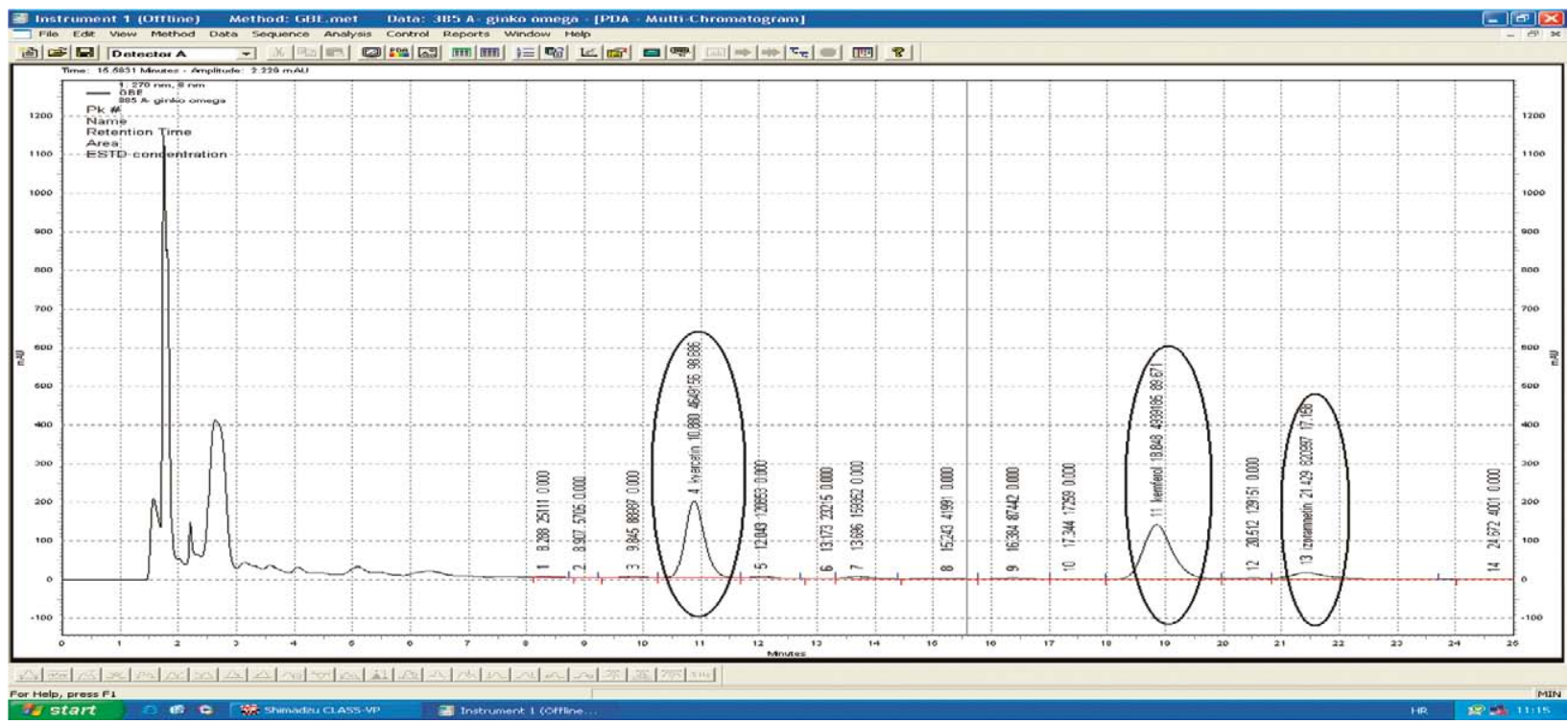

Fig. 15. Chromatogram of a valid genistein-free sample.

Even though both samples conformed to the labeled information on the established GBE quantity calculated based on the established quantity of ginkgo flavone glycosides, suspicion of their safety arose as soon as kaempferol concentrations markedly higher than those of quercetin $(\mathrm{Q} / \mathrm{K}: 0.84$ and 0.83 , respectively) were established. The documented peak atypical of GBE, identified as a phytoestrogen falling into the group of isoflavones, that is, genistein, was an additional indication of possible counterfeiting of ginkgo extract in the target samples by virtue of Fructus sophorae (Sophora japonica L.) extract addition.

\section{Discussion}

According to the reports submitted by sanitary inspections, GBE counterfeiting has been witnessed not 
only in Croatia, but also in other EU member states; even more so, Ginkgo biloba L.-based products fall into the category of most often counterfeited food supplements of herbal origin.

The results of this study showed the quercetin/ kaempferol ratio (of 0.84 ) out of the ordinary for standardized GBE-based products and reaching the lower limit of the ratio span quoted in the reference literature (0.8-1.65) to be established in $20 \%$ of the samples analyzed. Analysis of the HPLC chromatograms revealed the results to be indicative of counterfeiting; judging by the results obtained, in the products in reference, GBE was substituted with a cheaper Sophora japonica L. extract, thereby misleading the consumers that ultimately failed to achieve the therapeutic effect expected to be achieved should a genuine GBE be consumed. Due to its acting mechanisms that mimic those of estrogen hormones, the presence of genistein, i.e. a phytoestrogen falling into the group of isoflavones, could result in adverse pharmacological effects in some consumer groups; therefore, the presence of genistein should unanimously be advertised on the products containing it.

This study confirmed the importance of continuous control of products containing the Ginkgo biloba L. plant extract. This control should make use of a standardized technique and proper interpretation of its results. The technique chosen to be employed to the above effect should allow not only for determination of shares of the three major ginkgo flavone glycosides, but also determination of their mutual ratios; otherwise, an invalid sample might be adjudicated as valid. Namely, should the analysis be boiled down solely to determination of the three major flavone glycosides, the possible substitution of GBE with a certain amount of plant extract of other origin but similar flavonoid composition, or possible spiking of the preparation with quercetin not originating from the Ginkgo biloba L. might go under the radar, since the total amount of ginkgo flavone glycosides contained by counterfeit drugs most often complies with the labeled amount.

Because of their marked biological activity and profound influence on human health, prior to their marketing authorization, the products containing Ginkgo biloba L. should be registered with and approved by the Ministry of Health. The issue here is the fact that once authorized for sale, a product usually ceases to be a subject of quality control, which makes the trueness of the label statements dubious, and might compromise the expected health effects and misguide consumers.

Of note, comparison of the results of our study with the results of the monitoring program launched by the Ministry of Health and carried out under the roof of the Croatian Public Health Institute in 2008, during the course of which over $76 \%$ of the samples analyzed were unmasked as invalid (as regards the total amount of GBE and/or quercetin/kaempferol ratio), revealed that, since then, counterfeiting of Ginkgo biloba L.-based products in the Republic of Croatia has decreased in frequency by almost 50\%. By all means, this favorable trend comes as a result of two additional monitoring programs launched by the Ministry of Health in the last seven years, as well as of the activities of competent authorities taken post monitoring, which resulted in mandatory withdrawal of invalid products from the market, their market re-release being granted solely provided that their formulation has been duly corrected in terms of adding a genuine GBE, as corroborated by subsequent analysis of the corrected products.

\section{Conclusions}

The results of the analysis of ginkgo flavone glycosides in the products comprising the Ginkgo biloba L. plant extract, marketed in the form of food supplements and pure GBE-based products, revealed $20 \%$ of the samples to be counterfeited, meaning that their actual composition did not comply with the composition advertised on the label, which could easily deceive potential consumers. The extract of the Sophora japonica L. plant, found in two counterfeit products, does not act in the same pharmacological manner as does the Ginkgo biloba L. extract declared as present in these preparations, due to which the users of the counterfeit drugs failed to benefit from the expected pharmacological effects. A false label that intentionally neglects to inform consumers about the presence of the Sophora japonica L. extract actually deprives them of the information on the presence of pharmacologically active genistein, a phytoestrogen which, due to the similarity of its acting mechanisms with those of estrogen hormones, might exhibit adverse effects in some consumer 
groups and should therefore always be clearly declared as present in any product comprising it.

Beneficial effects of Ginkgo biloba L. ingredients in terms of human health preservation and improvement can be achieved solely by virtue of administration of authentic and standardized plant extracts. The everincreasing presence of counterfeit drugs on the global market can be decreased only through continuous control of safety and appropriateness of the marketed products. Analytical techniques employed to this end should be reliable and acknowledged, while the final product safety report should inform not only on the total amount of ginkgo flavone glycosides, but also on their mutual ratios, and should provide solid evidence for GBE genuineness.

\section{References}

1. World Health Organization. WHO monographs on selected medicinal plants. Vol. 2. World Health Organization. 1999. p. 154-67. (available at: https://books.google.hr/books?hl=hr\&lr $=\& \mathrm{id}=\mathrm{qWP} 4 \mathrm{aG}-\mathrm{wXAQC} \& \mathrm{xi}=$ fnd $\& p \mathrm{pg}=\mathrm{PR} 5 \& \mathrm{dq}=1 . \% 09 \mathrm{Wor}$ ld+Health+Organization. $+\mathrm{WHO}+$ monographs+on+selected+ medicinal+plants.+Vol.+2.+World + Health + Organization. +199 9.+p.+154-167.\&ots=RLx3wXRAlj\&sig=NMYbiGGLQ3bR mepYPkb4SwVDOck\&redir_esc $=y \# v=$ onepage\&q\&f=false accessed 1.1.2018.)

2. Consultation E. Committee on Herbal Medicinal Products (HMPC). 2008. (available at: http://data.ellispub.com/pdf/ EN/2008/EMEA/10130308en.pdf, accessed Jan 1, 2018)

3. Beek TAV. Ginkgo biloba: Medicinal and Aromatic Plants. Amsterdam: Taylor Francis e-Library, 2000; p. 475-90.

4. Cheng SY, Xu F, Wang Y. Advances in the study of flavonoids in Ginkgo biloba leaves. J Med Plants Res. 2009;3(13):1248-52. (available at: http://www.academicjournals.org/JMPR, accessed Jan 1,2018)

5. Lin LZ, Chen P, Ozcan M, Harnly JM. Chromatographic profiles and identification of new phenolic components of Ginkgo biloba leaves and selected products. J Agric Food Chem. 2008;56(15):6671-9. (available at: https://doi.org/10.1021/ jf800488x, accessed Jan 1, 2018)

6. Gray D, LeVanseler K, Pan M, Waysek EH, Chandra A. Evaluation of a method to determine flavonol aglycones in Ginkgo biloba dietary supplement crude materials and finished products by high-performance liquid chromatography: collaborative study. J AOAC Int. 2007;90(1):43-53. https://europepmc. org/articles/pmc2602960, accessed Jan 1, 2018)

7. Huang SH, Lewis TM, Lummis SC, Thompson AJ, Chebib M, Johnston GA, Duke RK. Mixed antagonistic effects of the ginkgolides at recombinant human $\rho 1$ GABA C receptors. Neuropharmacology. 2012;63(6):1127-39. (available at: https: //doi.org/10.1016/j.neuropharm.2012.06.067, accessed Jan1, 2018)

8. Park JW, Kwon HJ, Chung WS, Kim CY, Seong GJ. Shortterm effects of Ginkgo biloba extract on peripapillary retinal blood flow in normal tension glaucoma. Korean J Ophthalmol. 2001;25(5):323-8. (available at: http://dx.doi.org/10.1136/bjo. 83.4.466, accessed Jan 1, 2018)

9. Usai S, Grazzi L, Bussone G. Ginkgolide B as migraine preventive treatment in young age: results at 1-year follow-up. Neurol Sci. 2011;32(1):197-9. doi: 10.1007/s10072-011-05227 (available at: https://insights.ovid.com/ngsc/201105001/ 00128855-201105001-00044, accessed Jan 1, 2018)

10. Szczurko O, Shear N, Taddio A, Boon H. Ginkgo biloba for the treatment of vitiligo vulgaris: an open label pilot clinical trial. Complement Alternative Med. 2011;11:21-30. (available at: http://www.biomedcentral.com/1472-6882/11/21, accessed Jan 1, 2018)

11. Wesnes KA, Faleni RA, Hefting NR, Hoogsteen G, Houben JJG, Jenkins E, Jonkman JHG, Petrin LJ. The cognitive, subjective, and physical effects of a Ginkgo biloba/Panax ginseng combination in healthy volunteers with neurasthenic complaints. Psychopharmacol Bull. 1997;33:677-83.

12. Ernst E, Stevinson C. Ginkgo biloba for tinnitus. Clin Otolaryngol Allied Sci. 1999;24(3):164. (available at: https://doi. org/10.1046/j.1365-2273.1999.00243.x, accessed Jan 1, 2018)

13. Kleijnen J, Knipschild P. Ginkgo biloba for cerebral insufficiency. Br J Clin Pharmacol. 1992;34(4):352-8. (available at: https:// doi.org/10.1111/j.1365-2125.1992.tb05642.x, accessed Jan 1, 2018)

14. Rouse J. Ginkgo biloba: Mind, Mood, and Memory. Clinical Nutrition Insights. Advanced Nutrition Publications Inc., 1998;6(7):1 2 .

15. DeKosky ST, Williamson JD, Fitzpatrick AL, Kronmal RA, Ives DG, Saxton JA, et al. Ginkgo biloba for prevention of dementia. JAMA. 2008;300(19):2253-62. doi: 10.1001/jama. 2008.683 (available at: http://citeseerx.ist.psu.edu/viewdoc/ download?doi=10.1.1.692.3171\&rep=rep1\&type=pdf, ac cessed Jan 15, 2018)

16. Le Bars LP, Katz MM, Berman N, Itil, TM, Freedman AM, Schatzberg AFA. Placebo-controlled, double-blind, randomized trial of an extract of Ginkgo biloba for dementia. JAMA. 1997;278(16):1327-32. doi: 10.1001/jama.1997.0355016004 7037

17. Oken BS, Storzbach DM, Kaye JA. The efficacy of Ginkgo biloba on cognitive function in Alzheimer disease. Arch Neurol. 1998;55:1409-15. doi: 10.1001/archneur.55.11.1409 (available at: https://jamanetwork.com/journals/jamaneurology/fullarticle/774397, accessed Feb 2, 2018)

18. Brinkley TE, Lovato JF, Arnold AM, et al. Effect of Ginkgo biloba on blood pressure and incidence of hypertension in elderly men and women. Am J Hypertens. 2010;23:528-33. (available at: https://doi.org/10.1038/ajh.2010.14, accessed Feb 10, 2018) 
19. Turan I, Martorano D. Natural substances in psychiatry (Ginkgo biloba in dementia). Psychopharmacol Bull. 1995;31:147-58.

20. American Analytical Chemistry Laboratories. Pattern recognition of flavone glycosides is important for Ginkgo biloba extract analytical solution. Am Anal Chem Lab. 2007;3(5):1-10.

21. Uríková $A$, Babušíková E, Dobrota $D$, Drgová $A$, Kaplán $P$, Tatarková Z, Lehotský J. Impact of Ginkgo biloba extract EGb 761 on ischemia/reperfusion-induced oxidative stress products formation in rat forebrain. Cell Mol Neurobiol. 2006;26:134151. (available at: https://doi.org/10.1007/s10571-006-9030-3, accessed Jan 21, 2018)

22. Yang D, Gan LJ, Shin JA, Kim S, Hong ST, Park SH, et al. Antioxidative activities of Ginkgo biloba extract on oil/water emulsion system prepared from an enzymatically modified lipid containing alpha-linolenic acid. J Food Sci. 2013;78:1. (available at: https://doi.org/10.1111/j.1750-3841.2012.03010.x

23. Ruining L, Xueli W, Yunan Z, Zhixing W, Lijun D. The uptake behaviours of kaempferol and quercetin through rat primary cultured cortical neurons. Biomed Chromatogr. 2006;20(11): 1178-84. (available at: https://doi.org/10.1002/bmc.675, accessed Jan 31, 2018)

24. Jezova D, Duncko R, Lassanova M, Kriska M, Moncek F. Reduction of rise in blood pressure and cortisol release during stress by Ginkgo biloba extract (EGB 761) in healthy volunteers. J Physiol Pharmacol. 2002;53:337-48. (available at: http://jpp. krakow.pl/journal/archive/09_02/pdf/337_09_02_article.pdf, accessed Jan 1, 2018)

25. Lee KH, Park E, Lee HJ, Kim MO, Cha YJ, Kim JM, Shin MJ. Effects of daily quercetin-rich supplementation on cardiometabolic risks in male smokers. Nutr Res Practice. 2011;5(1): 28-33. (available at: https://doi.org/10.4162/nrp.2011.5.1.28, accessed Jan 8, 2018)

26. David AVA, Arulmoli R, Parasuraman S. Overviews of biological importance of quercetin: a bioactive flavonoid. Pharmacognosy Rev. 2016;10(20):84. (available at: https://dx.doi. org/10.4103\%2F0973-7847.194044, accessed Feb 1, 2018)

27. Ivic L, Sands TJ, Fishkin N, Nakanishi K, Kriegstein AR, Strømgaard K. Terpene trilactones from Ginkgo biloba are antagonists of cortical glycine and GABAA receptors. J Biol Chem.2003;278(49):49279-85. doi: 10.1074/jbc.M304034200
28. Nakanishi K. Terpene trilactones from Ginkgo biloba: from ancient times to the $21^{\text {st }}$ century. Bioorganic Med Chem. 2005;13(17):4987-5000. (available at: https://doi.org/10.1016 /j.bmc.2005.06.014, accessed Jan 11, 2018)

29. Rider CV, Nyska A, Cora MC, Kissling GE, Smith C, Travlos GS, Kooistra L. Toxicity and carcinogenicity studies of Ginkgo biloba extract in rat and mouse: liver, thyroid, and nose are targets. Toxicol Pathol. 2014;42(5):830-43. (available at: https://doi. org/10.1177\%2F0192623313501235, accessed Jan 17,2018)

30. Saevels J, Corthout J. Ginkgo biloba medicines and food supplements on the Belgian market: a comparative study. J Pharm Belgique. 2005;60(4):129-34.

31. Clostre F. Ginkgo biloba L. extract (EGb 761). State of knowledge in the dawn of the year 2000. Ann Pharmaceut Francaises. 1999;57:1S8-88.

32. Viapiana A, Wesolowski M. The phenolic contents and antioxidant activities of infusions of Sambucus nigra L. Plant Foods Human Nutr. 2017;72(1):82-7. doi: 10.1007/s11130-0160594-x (available at: https://link.springer.com/article/10.1007/ s11130-016-0594-x, accessed Feb 11, 2018)

33. Asgarpanah J, Khoshkam R. Phytochemistry and pharmacological properties of Ruta graveolens L. J Med Plants Res. 2012;6(23):3942-9. doi: 10.5897/JMPR12.040

34. Kreft S, Knapp M, Kreft I. Extraction of rutin from buckwheat (Fagopyrum esculentum Moench) seeds and determination by capillaryelectrophoresis.J Agric Food Chem.1999;47(11):464952. (available at: https://doi.org/10.1021/jf990186p, accessed Feb 1, 2018)

35. Tumir H, Bošnir J, Vedrina-Dragojević I, Dragun Z, Tomić S, Puntarić D, Jurak G. Monitoring of metal and metalloid content in dietary supplements on the Croatian market. Food Control. 2010;21(6):885-9. (available at: https://doi.org/ 10.1016/j.foodcont.2009.12.005

36. Čulig B, Bevardi M, Bošnir J, Serdar S, Lasić D, Racz A, et al. Presence of citrinin in grains and its possible health effects. Afr J Tradit Complement Alternat Med. 2017;14(3):22-30. (available at: https://www.ajol.info/index.php/ajtcam/article/viewFile/154937/144534, accessed Jan 8, 2018) 
Sažetak

PROVJERA AUTENTIČNOSTI EKSTRAKTA LISTA BILJKE GINKGO BILOBA L. I PROIZVODA
KOJI GA SADRŽE NA HRVATSKOM TRŽIŠTU PUTEM ANALIZE KOLIČINE I OMJERA
GINKOFLAVONOGLIKOZIDA (KVERCETIN, KEMPFEROL I IZORAMNETIN) I TERPENSKIH
TRILAKTONA U SVRHU OTKRIVANJA KROVOTVORENIH PRIPRAVAKA OPASNIH
ZA ZDRAVLJE KORISNIKA

M. Budě́, J. Bošnir, A. Racz, D. Lasić, D. Brkić, A. Mosović Ćuic, Ž. Kubarić, G. Jurak i L. Barušić

Ginkgo biloba L. najstarija je biljka na zemlji, a pripravci od njegovih listova i sjemenaka dio su kineske medicine već više tisuća godina. Vrstu je 1771. godine otkrio Linnaeus, a ime je dobila od latinskih riječi bis, tj. dva i lobus zbog specifičnog oblika lista. Današnji farmaceutski oblici biljke Ginkgo biloba L. sadrže uglavnom ekstrakte iz listova ubranih ujesen kada je najveća koncentracija aktivnih komponenata. Suvremenim istraživanjima određen je kemijski sastav njegovog lista, a utvrđeni su i mehanizmi njegovog pozitivnog djelovanja na reološka svojstva krvi i ubrzanje njezinog protoka. Visoka cijena i velika popularnost ubrzo su postali poticaj za krivotvorenje ekstrakta biljke Ginkgo biloba L. jeftinijim ekstraktima drugih biljaka. Naime, suvremeni medicinski proizvodi i dodaci prehrani na osnovi biljke Ginkgo biloba L. sadrže ekstrakte njegovog lista koji se standardiziraju prema njegovim ključnim farmakološki aktivnim sastavnicama; najčešće je to $22 \%$-27\% flavonoid glikozida i 6\%-7\% terpenskih trilaktona. Kvercetin, kempferol i izoramnetin su dominantni i farmakološki najvažniji flavonoidi, a njihova ukupna količina i međusobni omjeri nedvojben su pokazatelj autentičnosti ekstrakta. Stoga se i većina analiza za utvrđivanje ispravnosti proizvoda koji sadrže biljku Ginkgo biloba L. temelji na analizi ovih parametara. Krivotvorenja podrazumijevaju djelomičnu ili potpunu zamjenu ektrakta Ginkgo biloba L. nekim jeftinijim biljnim ekstraktom sličnog sastava uz eventualno obogaćivanje dodatnom količinom flavonoida, najčešće kvercetina, koji ne potječu od biljke Ginkgo biloba L. Svrha ovoga rada bila je provjeriti autentičnost i kakvoću pripravaka Ginkgo biloba L. na hrvatskom tržištu. Analizirano je ukupno 10 uzoraka različitih proizvođača. Kao pokazatelji njihove ispravnosti određivani su udjeli aglikona karakterističnih ginkoflavonoglikozida: kvercetin, kempferol i izoramnetin te omjeri nađenih količina kvercetina i kempferola kao ključni pokazatelji krivotvorenja ginkgo-ekstrakta. Količina ginkoflavonoglikozida određena je metodom tekućinske kromatografije visoke djelotvornosti. Analizom je utvrđeno da $80 \%$ uzoraka odgovara navodima deklaracije u pogledu ukupne količine flavonoglikozida kao i u pogledu njihovog međusobnog omjera. U 20\% uzoraka omjer kvercetina i kempferola odstupao je od uobičajenih vrijednosti, a dokazano je i prisustvo fitoestrogena genisteina, jedne od karakterističnih sastavnica biljke Sophora japonica L., čijim ekstraktom je krivotvoren ginkgo-ekstrakt u analiziranim uzorcima. Zbog neistinite deklaracije na proizvodima koji su sadržavali ove ekstrakte izostalo je i obvezno upozorenje o prisutnosti farmakološki aktivnog genisteina koji može izazvati neželjene zdravstvene posljedice kod pojedinih skupina potrošača. Rezultati ovoga rada ukazuju na značajnu pojavnost krivotvorenja proizvoda biljke Ginkgo biloba L. na hrvatskom tržištu te se zbog toga predlaže njihova temeljitija kontrola kao i sankcioniranje neodgovornih proizvođača i trgovaca, čime bi se doprinijelo većem udjelu kvalitetnijih proizvoda i izbjegli zdravstveni rizici te smanjila pojavnost prijevare.

Ključne riječi: Ginkgo biloba; Kvercetin; Krivotvoreni lijekovi; Hrvatska 